\title{
Recovery from hypoxia with and without sulfide in Saduria entomon: oxygen debt, reduced sulfur and anaerobic metabolites
}

\author{
Bent Vismann*, Lars Hagerman \\ Marine Biological Laboratory, Strandpromenaden 5, DK-3000 Helsingør, Denmark
}

\begin{abstract}
The Baltic brackish water isopod Saduria entomon was exposed $\left(8 \mathrm{~h} ; \mathrm{T}: 11^{\circ} \mathrm{C} ; \mathrm{S}: 10 \mathrm{ppt}\right\}$ to hypoxia $(0.1 \mathrm{kPa})$ and to hypoxia $(0.7 \mathrm{kPa})$ with sulfide $(41 \mu \mathrm{M})$. Oxygen consumption was measured using computer-controlled intermittent respirometry. The routine oxygen consumption was $0.109 \mathrm{mg}$ $\mathrm{O}_{2} \mathrm{~h}^{-1} \mathrm{~g}^{-1}$ at normoxia $(19.5 \mathrm{kPa})$. The recovery from hypoxia with and without sulfide was studied in terms of oxygen debt, reduced sulfur concentration and anaerobic metabolites. In hypoxia, the metabolism of $S$. entomon was reduced by $70 \%$ compared to the normoxic level and the oxygen debt was $0.57 \mathrm{mg} \mathrm{O}_{2} \mathrm{~g}^{-1}$ Normal respiration rate was re-established after $8 \mathrm{~h}$ of recovery. Lactate oxidation accounted for $44 \%$ of the oxygen debt. in hypoxia with sulfide, the metabolism was reduced by $38 \%$ compared to the normoxic level and the oxygen debt was $2.74 \mathrm{mg} \mathrm{O}_{2} \mathrm{~g}^{-1}$ (5 times the oxygen debt at hypoxia). Normal respiration level was not restored until $28 \mathrm{~h}$ after exposure. Lactate oxidation accounted for only $20 \%$ of the oxygen debt. Sulfide and detoxification products accounted for as little as $0.04 \%\left(1 \mu \mathrm{g} \mathrm{O}_{2} \mathrm{~g}^{-1}\right.$ wet wt $)$ of the oxygen debt. The majority $(80 \%)$ of processes that occurred during the recovery from sulfide exposure are inferred to be involved in restoring normal cell function. Removal of internal sulfide and reoxidation of anaerobic metabolites play secondary roles
\end{abstract}

KEY WORDS: Sulfıde Hypoxia Recovery Oxygen debt Anaerobic metabolites Saduria entomon

\section{INTRODUCTION}

Marine animals from sulfidic habitats have some degree of sulfide tolerance (reviewed by Somero et al. 1989, Vismann 1991a and Bagarinao 1992). In the literature, studies of sulfide tolerance have focussed on processes occurring during sulfide exposure. Little attention has been given to processes occurring after the exposure. Surviving animals may be moribund or recovering. Hence, the processes occurring during and after exposure to sulfide are equally important for the survival. Knowledge of the physiological mechanisms at work during recovery from sulfide exposure will improve our understanding of the physiology of animals exposed to sulfide.

Most species from sulfidic habitats detoxify sulfide by oxidation to thiosulfate and turn to an anaerobic

•E-mail:mblbv@inet.uni-c.dk metabolism if the sulfide concentration at the mitochondrial level exceeds approximately $20 \mu \mathrm{M}$ (Powell \& Somero 1986, Bagarinao \& Vetter 1990, Oeschger \& Vismann 1994), even if sufficient oxygen to permit aerobic metabolism is present (Oeschger \& Vetter 1992, Völkel \& Grieshaber 1992, Hagerman \& Vismann 1993, 1995). The toxic effect of sulfide is primarily a reversible inhibition of cytochrome $c$ oxidase (National Research Council 1979). As most animals turn to an anaerobic metabolism during sulfide exposure, the need for detoxification is not obvious. However, sulfide has been shown to affect the survival of animals relying on anaerobic energy metabolism for protection (Theede 1969, Vismann 1990). The need to detoxify sulfide during anaerobiosis, therefore, potentially exists.

A successful recovery from sulfide poisoning depends on a quick return to an aerobic metabolism. This is possible only if cytochrome coxidase is not inhibited 
by sulfide. Regardless of metabolic state, detoxification of sulfide will facilitate the recovery from sulfide poisoning by keeping the internal sulfide concentration as low as possible. In order to restore the internal environment, numerous processes takes place during recovery (e.g. oxidation of anaerobic metabolites, removal of detoxification products, osmotic and ionic regulation, protein synthesis, regeneration of phosphogen, regeneration of ATP stores, and replenishment of physically dissolved and pigment-bound oxygen). Oxygen used in these processes is referred to as oxygen debt (Herreid 1980, Ellington 1983). Oxygen debt is seen as a temporary increase above the normal level of normoxic oxygen consumption. The significance of the different processes occurring during the recovery can be stoichiometrically evaluated in terms of oxygen equivalents.

The objective of the present study was to elucidate the physiological differences between the recovery from anaerobiosis induced by sulfide and recovery from lack of oxygen in the sulfide-tolerant isopod Saduria entomon. Emphasis is on the temporal progression of oxygen debt, reoxidation of anaerobic metabolites and reduced sulfur.

\section{MATERIALS AND METHODS}

Material. Saduria entomon were collected in the Aland archipelago, Finland, off the Husö Marine Biological Station, and in the Gulf of Gdansk, Poland, during 1995. The isopods were transported to the Marine Biological Laboratory, Helsingor, Denmark. Prior to experiments, S. entomon were kept in large tanks with natural sediment and fully aerated water $\left(T=7^{\circ} \mathrm{C}: \mathrm{S}=8 \mathrm{ppt}\right.$ ). They were fed Mytilus edulis once a week

Exposure experiments. Experimental set-up: All exposures were made using a set-up in which. $\mathrm{pH}$, sulfide, oxygen and temperature were monitored and controlled by a computer. Oxygen tension was measured with an oxygen electrode (Radiometer, Copenhagen, Denmark; E5046, modified according to the pnnciples of Revsbech \& Ward 1983) and a reference electrode (Radiometer $\mathrm{K} 401$ ) connected to a $\mathrm{pH} /$ blood gas monitor (Radiometer PHM73). The $\mathrm{pH}$ was measured with an electrode (Radiometer pHC2401) connected to the $\mathrm{pH} / \mathrm{blood}$ gas monitor. Sulfide potential was measured with an ion selective $\mathrm{Ag}-\mathrm{Ag}_{2} \mathrm{~S}$ electrode (laboratory constructed) and a reference electrode (Radiometer K401) connected to an ion analyzer (Radiometer Ion 85). Temperature was measured with a thermistor probe (Yellow Springs Instrument $\mathrm{Co} ., \mathrm{OH}_{\text {, USA; }}$
700 series) connected to a thermistor panel (ColeParmer Instrument Co., IL, USA; 700 series). The signals from the meters measuring $\mathrm{pH}$, sulfide, oxygen and temperature were fed into the computer at a frequency of $0.5 \mathrm{~Hz}$ (Fig. 1. signals). The computer compared the signals with preset set-points. Signals outside their respective hysteresis caused the computer to turn on the appropriate pumps or magnetic valves (Fig 1: output). The sulfide potential was continuously converted by the computer to sulfide concentration according to the appropriate equations (Vismann 1996). The water in the aquarium (vol $=6$ l) was mixed by 2 centrifugal pumps (Eheim $\mathrm{GmbH}$, Deizisau, Germany; 1048 and 1005; Fig. 1: pumps D and E). The 2 pumps had a total flow rate of $14.51 \mathrm{~min}^{-1}$. Data for post experimental analysis were saved on disk with a frequency of $8.3 \times 10^{-3} \mathrm{~Hz}$ (for further details see Vismann 1996). Temperature was only monitored by the computer because it was controlled by a constant thermobath (Hetofrig, Lab Equipment AS, Allerød, Denmark). Before and after each exposure salinity was measured with a refractometer (Atago Co., Tokyo, Japan).

Experimental conditions: In a series of experiments, Saduria entomon was exposed to normoxia, severe hypoxia and hypoxia with sulfide (the latter condition is referred to as sulfide in the following text). The hypoxic level in the sulfide exposure would, if sulfide was not present, allow $S$. entomon to use aerobic metabolism

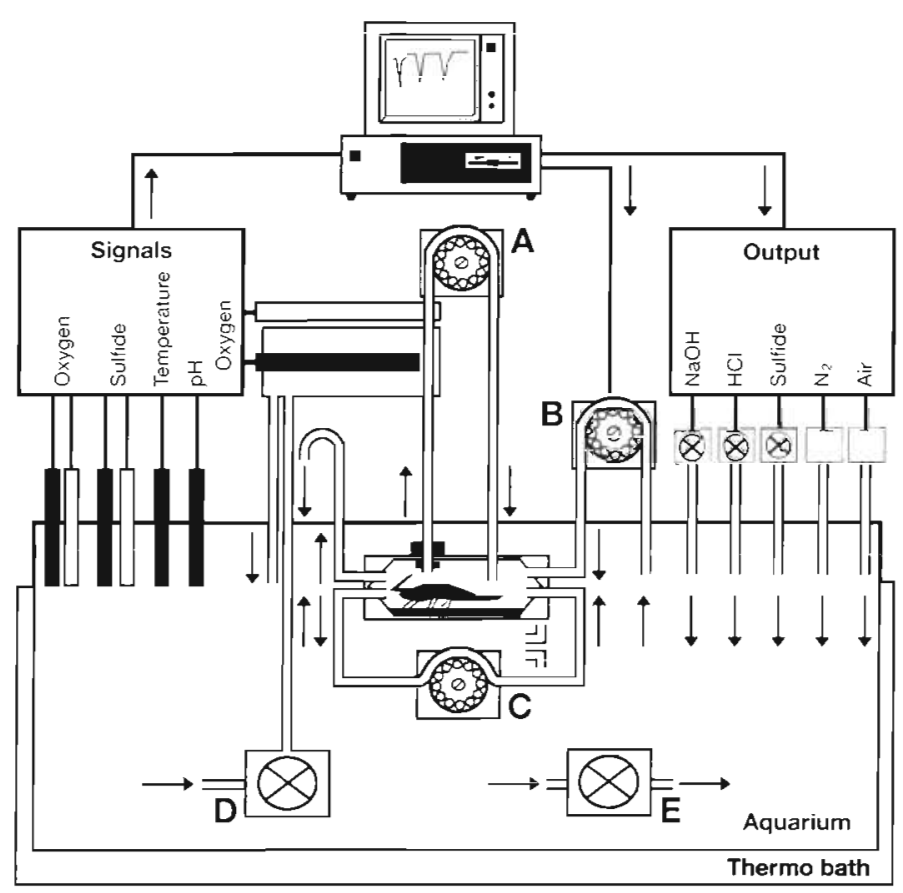

Fig. 1 Experimental set-up for exposure to hypoxia with and without sulfide and intermittent respirometry. See text for further details 
(Hagerman \& Szaniawska 1988). In the hypoxia and sulfide exposures, the protocol was: normoxia for the first $10 \mathrm{~h}$ (acclimation period), followed by $8 \mathrm{~h}$ of hypoxia with or without sulfide (exposure period) and then normoxia until routine respiration was restored (recovery period). The water in the aquarium was renewed before the recovery period. The protocol was produced by the computer by defining different set-points for the 3 experimental periods. The experimental conditions in the exposures are given in Table 1. It was not possible to renew the water completely and accordingly in the sulfide experiments a small amount of residual sulfide was initially present in the recovery period (Table 1). In a series of pilot experiments, the rate of chemical oxidation of residual sulfide was determined. The rate of oxygen use in residual sulfide oxidation was best fitted to an exponential equation $\left[\mathrm{MO}_{2}=0.6632 \mathrm{e}^{-04302 t}\right.$ where $t=$ time (h); $\mathrm{R}^{2}=0.88$; data not shown]

Respirometry. Experimental set-up: The oxygen consumption was measured using intermittent respirometry (see, e.g., Forstner 1983). In this method, the respiration chamber $(\mathrm{vol}=42 \mathrm{ml}$ ) changed between being a closed system and being flushed with water from the aquarium as explained below. During the flush period, the respiration chamber was flushed $\left(23.5 \mathrm{ml} \mathrm{min}^{-1}\right)$ with water from the aquarium by a peristaltic pump (Gilson Medical Electronics, Middleton, USA; minipuls 3, Fig. 1: pump B). The oxygen tension in the respiration chamber was measured via a shunt using an oxygen electrode (Radiometer E5046, modified according to the principles of Revsbech \& Ward 1983) installed in a constant temperature cell (Radiometer D616) and a reference electrode (Radiometer K401) both connected to a $\mathrm{pH} /$ blood gas monitor (Radiometer PHM73). The shunt (flow rate $=3.7 \mathrm{ml} \mathrm{min}^{-1}$ ) was driven by a peristaltic pump (Ismatec Sa, Zürich, Switzerland; Mini-S 840; Fig. 1: pump A). The flow of cooling water (10 l $\mathrm{min}^{-1}$ ) through the constant temperature cell was deliv- ered by a centrifugal pump (Eheim 1048; Fig. 1: pump D). Additional mixing of the respiration chamber was provided by a peristaltic pump (Ismatec Mini-S 840; flow rate $=3.7 \mathrm{ml} \mathrm{m^{-1 }}$; Fig. 1: pump C). Every $20 \mathrm{~min}$ the computer stopped flushing for 10 min (Fig. 1. inactivation of pump B), turning the respiration chamber into a closed system. In these periods, the computer sampled the chamber oxygen tension with a frequency of $8.3 \times 10^{-3} \mathrm{~Hz}$ and stored it on a disk in a separate file. As the chamber was closed during these periods, the consumption of oxygen caused the chamber oxygen tension to decrease. The decrease in oxygen tension in closed systems is linear if oxygen consumption is constant. The oxygen consumption was defined as the slope of the linear regression line and the coefficient of determination $\left(\mathrm{R}^{2}\right)$ provided a measure of the constancy of oxygen consumption (see Fig. 2). Oxygen consumption rates with $R^{2}<0.80$ were regarded as not being constant and they were excluded from the data-set (less than $3 \%$ of more than 600 measurements). The oxygen consumptions used in calculations had a mean $\mathrm{R}^{2}$ of $0.96 \pm 0.04$. Immediately before and after each experiment, the blank oxygen consumption of the system was measured. The blank oxygen consumption as a function of time was regarded as linear.

Oxygen debt: Oxygen consumption was measured during the recovery period following hypoxia and sulfide exposures. The oxygen consumption was also measured during the normoxic control experiments For each recovery period, the total oxygen consumption was calculated by numerical integration (Simpson's approximation). The oxygen debt was calculated by subtracting the integrated mean routine oxygen consumption of a time period equal to the recovery period from total oxygen consumption. The oxygen used for chemical sulfide oxidation (see above) at the start of the recovery period was subtracted from the total oxygen consumption in the sulfide experiments.

Table 1. Experimental conditions. All data are mean values \pm SEM

\begin{tabular}{|c|c|c|c|c|c|c|c|}
\hline \multirow{2}{*}{$\begin{array}{l}\text { Experimental } \\
\text { period }\end{array}$} & \multirow{2}{*}{$\begin{array}{l}\text { Oxygen } \\
(\mathrm{kPa})^{\mathrm{c}}\end{array}$} & \multirow[t]{2}{*}{$\mathrm{pH}$} & \multicolumn{2}{|c|}{ Sulfide ( $\mu \mathrm{M})$} & \multirow{2}{*}{$\begin{array}{c}\text { Temperature } \\
\left({ }^{\circ} \mathrm{C}\right)\end{array}$} & \multirow{2}{*}{$\begin{array}{l}\text { Salinity } \\
\text { (ppt) }\end{array}$} & \multirow[t]{2}{*}{$\mathrm{n}$} \\
\hline & & & Total & $\mathrm{H}_{2} \mathrm{~S}$ & & & \\
\hline \multicolumn{8}{|l|}{ Normoxia } \\
\hline Normoxic control & $19.47 \pm 0.46$ & $8.09 \pm 0.04$ & $0.0 \pm 0.0$ & $0.0 \pm 0.0$ & $11.1 \pm 0.4$ & $10 \pm 1$ & 6 \\
\hline \multicolumn{8}{|l|}{ Severe hypoxia } \\
\hline Adaptation & $19.00 \pm 0.25$ & $8.09 \pm 0.02$ & $0.0 \pm 0.0$ & $0.0 \pm 0.0$ & $11.1 \pm 0.4$ & $10 \pm 1$ & 6 \\
\hline Exposure & $0.12 \pm 0.02$ & $8.83 \pm 0.01$ & $0.0 \pm 0.0$ & $0.0 \pm 0.0$ & $11.0 \pm 0.5$ & $10 \pm 1$ & 6 \\
\hline Recovery & $18.62 \pm 0.20$ & $8.39 \pm 0.09$ & $0.0 \pm 0.0$ & $0.0 \pm 0.0$ & $11.1 \pm 0.4$ & $10 \pm 1$ & 6 \\
\hline \multicolumn{8}{|l|}{ Hypoxia and sulfide } \\
\hline Adaptation & $20.26 \pm 0.27$ & $8.07 \pm 0.02$ & $0.0 \pm 0.0$ & $0.0 \pm 0.0$ & $11.4 \pm 0.6$ & $10 \pm 1$ & 6 \\
\hline Exposure & $0.68 \pm 0.09$ & $8.11 \pm 0.03$ & $41.2 \pm 6.5$ & $3.5 \pm 0.5$ & $11.1 \pm 0.6$ & $10 \pm 1$ & 6 \\
\hline Recovery & $20.03 \pm 0.36$ & $8.01 \pm 0.04$ & $1.1 \pm 1.1$ & $0.1 \pm 0.1$ & $10.6 \pm 0.4$ & $10 \pm 1$ & 6 \\
\hline
\end{tabular}




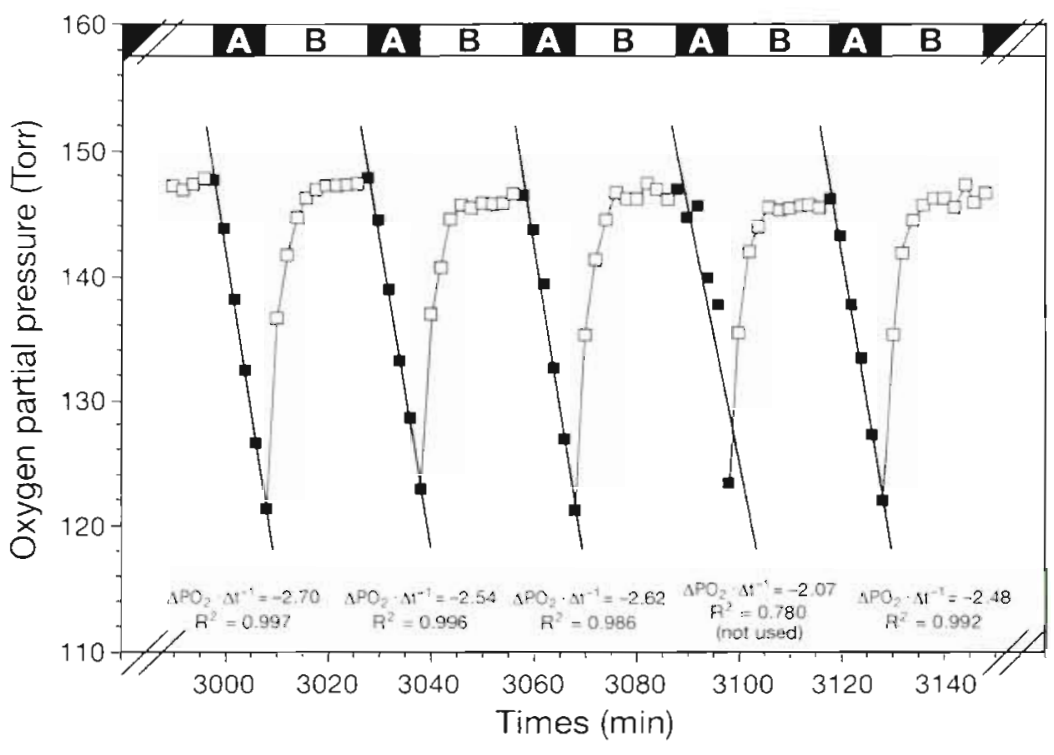

Fig. 2. Example of intermittent respirometry registered by computer (A) $10 \mathrm{~min}$

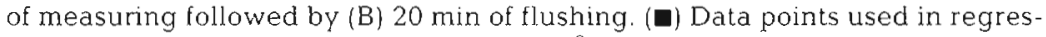
sion analysis. Regression equations and $\mathrm{R}^{2}$ shown for each line. The oxygen partial pressure 150 Torr is equivalent to $20 \mathrm{kPa}$

atmosphere and samples of the midgut gland and muscle tissue were removed. The samples were immediately (in the argon atmosphere) homogenized on ice in deoxygenated buffer [200 mM HEPES (N-2-hydroxyethyl piperazine-N'-2-ethane sulfonic acid) and 5 mM EDTA; pH 8.0] using a sonicator (Sonics and Materials, CT, USA; Vibra Cell VC50T). The homogenates were analyzed for reduced sulfur compounds using the monobromobimane technique (Fahey \& Newton 1987, Vetter et al. 1989). Sample treatment and HPLC analysis were performed according to Vismann (1991b). Elemental sulfur analysis was not made; it has earlier been shown that Saduria entomon does not produce $\mathrm{S}^{0}$ (Vismann 1991b).

Allometric calculations. All results were converted using the equations below and are presented as mol $\mathrm{g}^{-1}$ wet wt. It was assumed that lactate and

Chemical analysis. In addition to the Saduria entomon in the respiration chamber a number of $S$. entomon were incubated in the aquarium (Fig. 1). Half of these were taken for chemical analysis immediately after the exposure period and the rest at the end of the recovery period. From these $S$. entomon, the concentrations of anaerobic metabolites in the hemolymph and of reduced sulfur in the hemolymph, tissue and midgut gland were determined. Lactate and alanine were the only anaerobic metabolites considered in the present study following the results of Hagerman \& Szaniawska (1990) and Hagerman \& Vismann (1993).

Lactate: Hemolymph samples were taken with a hypodermic syringe (Hamilton, Bonaduz AG, Switzerland) inserted from a posterodorsal direction into the pericardium. The hemolymph samples $(50 \mu l)$ were immediately combined with $100 \mu \mathrm{l} 0.6 \mathrm{~N}$ perchloric acid and centrifuged at $3500 \times g$ for $10 \mathrm{~min}$. Lactate was then analyzed using a lactate kit (BoehringerMannheim, Germany; no. 139 084) and a spectrophotometer (Pharmacia L.KB Biotechnology, Uppsala, Sweden; Ultraspec plus) set at $340 \mathrm{~nm}$. Lactate analysis was made in all exposures.

Alanine: Hemolymph samples $(10 \mu l)$ were taken as above and analyzed for alanine by HPLC (Jasco, Tokyo, Japan; 880 PU) by pre-column reaction with orthophthalaldehyde and fluorescence detection (Jasco 820 FP), according to Gardner \& Miller (1980) Alanine analysis was made only in the sulfide exposures.

Reduced sulfur species: In the sulfide exposures a hemolymph sample $(50 \mu \mathrm{l})$ was taken as described above. The carapace was then removed in an argon alanine were homogeneously distributed throughout the soft parts of the Saduria entomon.

Oxygen: The oxygen consumption data were calculated for a $1 \mathrm{~g}$ isopod according to the allometric relation: $\mathrm{MO}_{2}=\mathrm{MO}_{2}{ }^{\prime} \cdot W^{-0.709}$ where $\mathrm{MO}_{2}{ }^{\prime}$ is the observed oxygen consumption corrected for blank (mg $\mathrm{O}_{2} \mathrm{~h}^{-1}$ ) and $W$ is the wet weight $(g)$ (data from Hagerman \& Szaniawska 1988)

Lactate, alanine and reduced sulfur: Concentrations of lactate, alanine and reduced sulfur were calculated for a $1 \mathrm{~g}$ isopod using allometric relations for the midgut gland, the remaining tissue (exoskeleton and gut excluded) and the hemolymph as described below.

Midgut gland and remaining tissue: The total wet weights of a number of Saduria entomon were determined. The midgut gland was dissected out and weighed. The gut was then removed and the remains were dried at $100^{\circ} \mathrm{C}$ for $2 \mathrm{~d}$. After $1 \mathrm{~h}$ in a desiccator, the dry weight was determined. The specimen was then heated at $455^{\circ} \mathrm{C}$ for $8 \mathrm{~h}$. After $1 \mathrm{~h}$ in a desiccator, the ash free dry weight was determined.

Hemolymph. Saduria entomon were first dried with Kleenex ${ }^{\otimes}$ and total wet weight was determined. The isopods were then cut open and after bleeding they were reweighed to determine hemolymph volume.

The Saduria entomon used were within the size range of 0.911 to $5.322 \mathrm{~g}$ total wet weight. Best fit was obtained using linear relationships. For the hemolymph, the midgut gland and the remaining tissue the slope of the line (with SD) and $R^{2}$ were $0.235 \pm 0.017$ $\left(R^{2}=0.89\right), 0.042 \pm 0.007\left(R^{2}=0.42\right)$ and $0.655 \pm 0.007$ $\left(R^{2}=1.00\right)$, respectively. 


\section{RESULTS AND DISCUSSION}

\section{Oxygen consumption}

Normoxia. The normoxic oxygen consumption as a function of time is seen in Fig. 3. The oxygen consumption is elevated due to initial stress during the first 3 h. Routine oxygen consumption was therefore calculated after excluding the first 3 h data. Regression analysis shows a slope which is not significantly different from zero $\left(R^{2}=0.09 ; p=0.093\right)$ and routine oxygen consumption was calculated as the mean value. Mean routine oxygen consumption ( \pm SEM) was $0.109 \pm 0.003 \mathrm{mg}$ $\mathrm{O}_{2} g^{-1} h^{-1}$. Hagerman \& Szaniawska (1988) found a routine oxygen consumption of $0.13 \mathrm{mg} \mathrm{O}_{2} \mathrm{~g}^{-1} \mathrm{~h}^{-1}$ in Saduria entomon buried in sand, and when not buried (i.e. active or stressed) oxygen consumption increased to $0.25 \mathrm{mg} \mathrm{O}_{2} \mathrm{~g}^{-1} \mathrm{~h}^{-1}$. Although sand was not used in the present study, the routine (and the stressed) oxygen consumption corresponds well with values found by Hagerman \& Szaniawska (1988).

\section{Severe hypoxia}

The oxygen consumption of Saduria entomon recovering from severe hypoxia is shown in Fig. 4 The

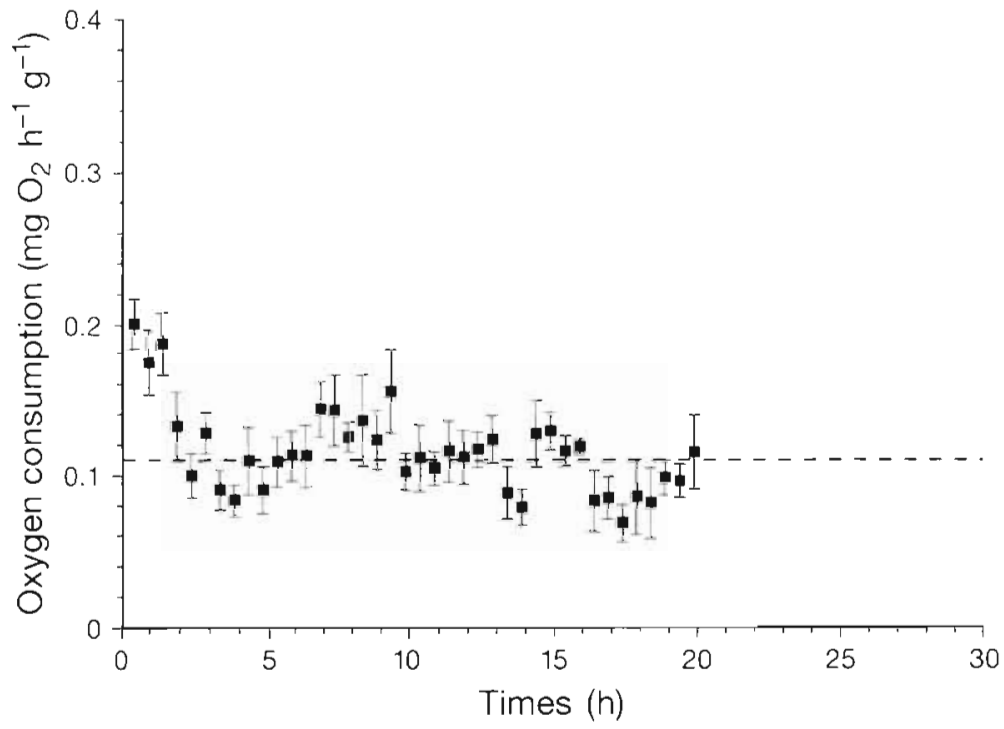

Fig. 3. Saduria entomon oxygen consumption during normoxia (19.5 kPa; $\left.T: 11^{\circ} \mathrm{C} ; \mathrm{S}: 10 \mathrm{ppt}\right)$. Data presented as mean values $\pm \mathrm{SEM}(\mathrm{n}=6) .(---)$ Mean normoxic oxygen consumption rate maximum oxygen consumption was $0.21 \pm 0.01 \mathrm{mg}$ $\mathrm{O}_{2} \mathrm{~g}^{-1} \mathrm{~h}^{-1}$. This point was reached after $1 \mathrm{~h}$ of recovery. The oxygen consumption returned to the normoxic level after $8 \mathrm{~h}$ of recovery. The oxygen debt was $0.57 \pm 0.05 \mathrm{mg} \mathrm{O}_{2} \mathrm{~g}^{-1}\left(17.8 \pm 1.6 \mu \mathrm{mol} \mathrm{O} \mathrm{O}_{2} \mathrm{~g}^{-1}\right)$. The time to recover from hypoxia is about the same as the exposure period; this has previously been found for other burrowing crustaceans (Bridges \& Brand 1980).

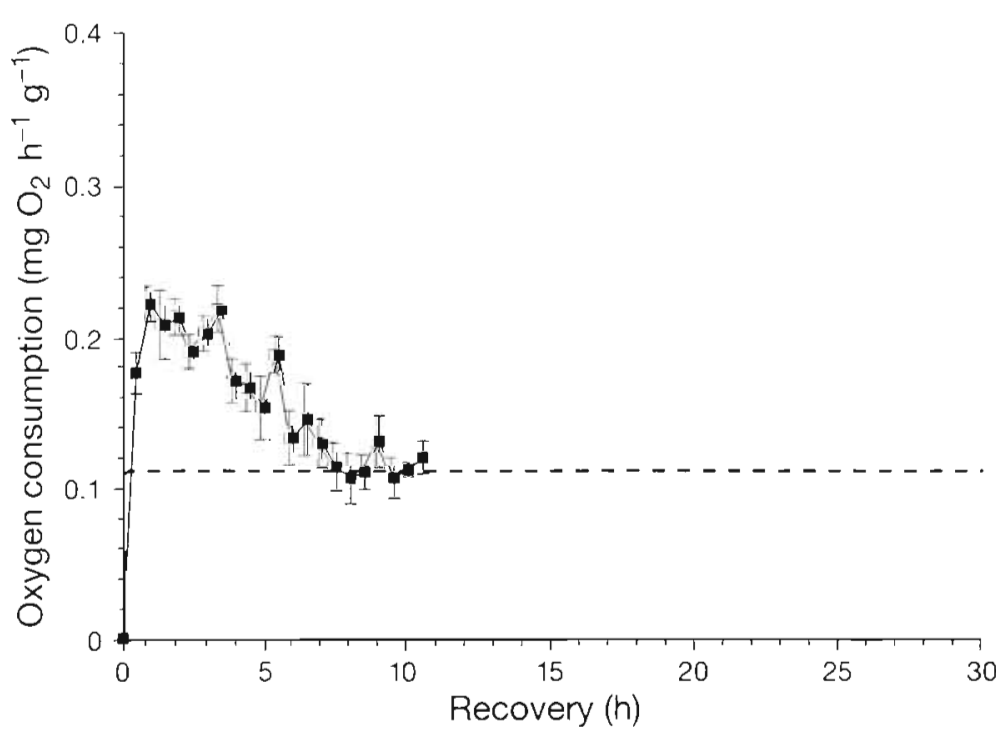

Fig. 4. Saduria entomon oxygen consumption during recovery from $8 \mathrm{~h}$ exposure to severe hypoxia $\left(0.1 \mathrm{kPa} ; T: 11^{\circ} \mathrm{C} ; \mathrm{S}: 10 \mathrm{ppt}\right)$. Data presented as mean values \pm SEM $(n=6)$. $(---)$ Mean normoxic oxygen consumption rate

\section{Hypoxia with sulfide}

The oxygen consumption of Saduria entomon recovering from hypoxia with sulfide is shown in Fig. 5. The maximum oxygen consumption was $0.33 \pm 0.02 \mathrm{mg}$ $\mathrm{O}_{2} \mathrm{~g}^{-1} \mathrm{~h}^{-1}$ and this point was reached after 7 to $8 \mathrm{~h}$ of recovery. The oxygen consumption returned to the normoxic level only after about $28 \mathrm{~h}$ of recovery. The oxygen debt was $2.74 \pm 0.29 \mathrm{mg} \mathrm{O}$ $\mathrm{g}^{-1}$ (i.e. $85.6 \pm 9.1 \mu \mathrm{mol} \mathrm{O} \mathrm{g}^{-1}$ ) or about 5 times the oxygen debt at hypoxia. The time to recover from sulfide exposure was significantly prolonged compared to the recovery from severe hypoxia. This contrasts with the finding of Oeschger \& Pedersen (1994), that the recovery period in the clam Scrobicularia plana was unaffected by the presence of sulfide. 


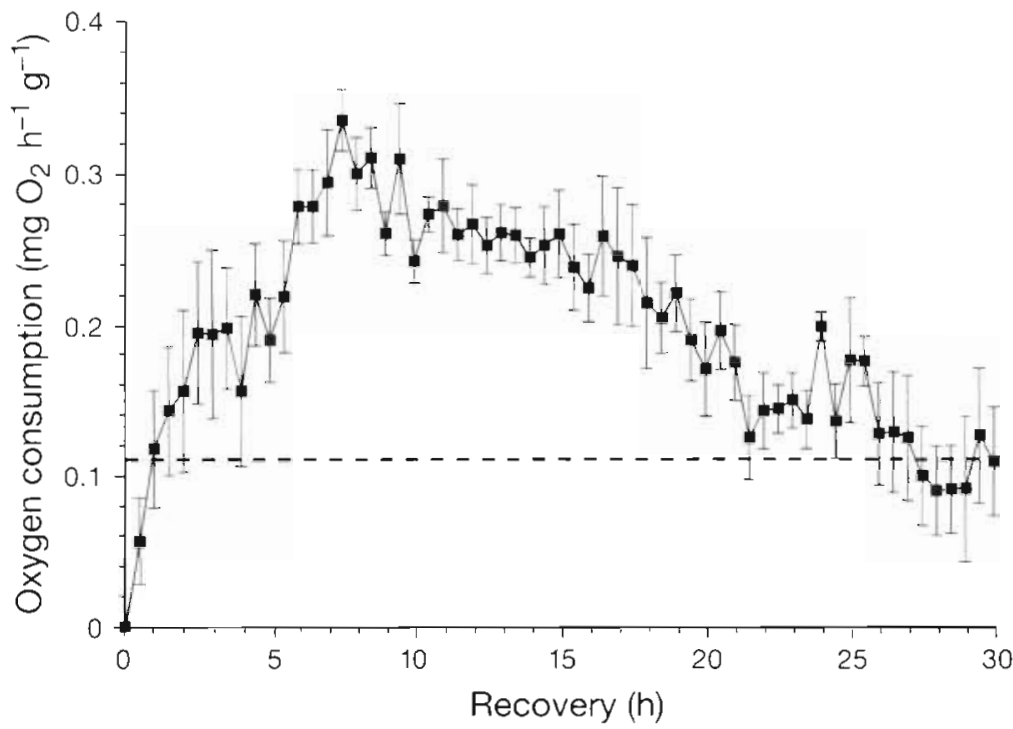

Fig. 5. Saduria entomon oxygen consumption during recovery from $8 \mathrm{~h}$ exposure to combined hypoxia $\left(0.7 \mathrm{kPa} ; \mathrm{T}: 11^{\circ} \mathrm{C}_{\mathrm{i}} \mathrm{S}: 10 \mathrm{ppt}\right)$ and sulfide $(50 \mu \mathrm{M}$ total sulfide). Data presented as mean values \pm SEM $(n=6)$. $(---)$ Mean normoxic oxygen consumption rate lactate ratio of $1.16 \pm 0.49$. An oxygen to lactate ratio $>0.5$ indicates that oxygen is used not only in the oxidative removal of lactate. Oxygen will also be used in the replenishment of physically dissolved oxygen and of hemocyanin-bound oxygen. Using a total oxygen carrying capacity of the hemolymph of $0.56 \mathrm{mmol} \mathrm{I}^{-1}$ (Hagerman \& Vismann 1997) this can only account for about $0.13 \mu \mathrm{mol} \mathrm{O}_{2} \mathrm{~g}^{-1}$. Regeneration of ATP and phosphogen stores are other possible processes using oxygen during the recovery from hypoxia (Herreid 1980). Using the oxygen to lactate ratio of 0.5 the lactate removed during recovery is equivalent to $7.7 \mu \mathrm{mol}$ $\mathrm{O}_{2} \mathrm{~g}^{-1}$ (0.25 $\mathrm{mg} \mathrm{O}_{2} \mathrm{~g}^{-1}$ ) and other processes consume $10.1 \mathrm{umol} \mathrm{O}_{2} \mathrm{~g}^{-1}$ $\left(0.32 \mathrm{mg} \mathrm{O}_{2} \mathrm{~g}^{-1}\right)$.

Following Hagerman \& Szaniawska (1990), the alanine concentration after $8 \mathrm{~h}$ exposure to anoxia is not significantly different from the normoxic level. Although not measured in the present

\section{Anaerobic metabolites}

Normoxia. Normoxic lactate concentration in Saduria entomon was $0.18 \pm 0.09 \mu \mathrm{mol} \mathrm{g}^{-1}(\mathrm{n}=3)$ in accordance with Hagerman \& Szaniawska (1990) and Hagerman \& Vismann (1993).

Severe hypoxia. After exposure to severe hypoxia, the lactate level $(\mathrm{n}=5)$ was $15.5 \pm 4.7 \mu \mathrm{mol} \mathrm{g}{ }^{-1}$. After recovery, the lactate returned to the normoxic level $\left(0.13 \pm 0.04 \mu \mathrm{mol} \mathrm{g}{ }^{-1} ; \mathrm{n}=3\right)$. During recovery, $15.4 \pm$ $4.7 \mu \mathrm{mol} \mathrm{g}^{-1}$ lactate was removed.

Oxygen to lactate ratio in severe hypoxia. Species which produce lactate during anaerobiosis depend on rapid lactate removal during recovery in order to avoid toxic effects (Hochacka \& Somero 1973). Removal of lactate can involve gluconeogenesis in which lactate is converted back to glucose (i.e. glucose-6-phosphate). Lactate accumulation and subsequent gluconeogenesis have been shown to be higher in species adapted to hypoxic conditions compared to species rarely exposed to hypoxic conditions (Hochacka \& Somero 1973, Pritchard \& Eddy 1979) Two molecules of lactate that have entered into gluconeogenesis use 6 high energy phosphate bonds to form 1 molecule of glucose-6-phosphate (Stryer 1975, Lehninger 1976). The aerobic metabolism produces about 6 ATP modules per $\mathrm{O}_{2}$ molecule consumed. The theoretical oxygen to lactate ratio is therefore 0.5 . In the present study, the oxygen debt was $17.8 \pm 1.6 \mu \mathrm{mol} \mathrm{g}^{-1}$ and the lactate removed in Saduria entomon recovering from severe hypoxia was $15.4 \pm 5.1 \mathrm{\mu mol} \mathrm{g}^{-1}$; giving an oxygen to study, alanine was certainly not accumulating in the severe hypoxia exposure. This can be seen from the fact that not even during 8 h of sulfide exposures did alanine accumulate (see below and Hagerman \& Vismann 1993).

Hypoxia with sulfide. After sulfide exposure the lactate level ( $\mathrm{n}=10$ ) was $36.1 \pm 5.0 \mu \mathrm{mol} \mathrm{g}{ }^{-1}$ and after recovery the lactate level $(n=3)$ had returned to the normoxic level $\left(0.18 \pm 0.01 \mu \mathrm{mol} \mathrm{g}^{-1}\right)$. During recovery, $35.9 \pm 5.0 \mu \mathrm{mol}$ lactate $\mathrm{g}^{-1}$ was removed. The oxygen to lactate ratio during sulfide exposure was $2.38 \pm 0.59$, showing an increased importance of other processes. Using the above oxygen to lactate ratio of 0.5 , the lactate removed is equivalent to $18.0 \pm 2.5 \mu \mathrm{mol} \mathrm{O} \mathrm{g}^{-1}$ $\left(0.58 \mathrm{mg} \mathrm{O}_{2} \mathrm{~g}^{-1}\right)$ used, and other processes consume $67.7 \mu \mathrm{mol} \mathrm{O} \mathrm{O}^{-1}\left(2.16 \mathrm{mg} \mathrm{O} \mathrm{O}^{-1}\right)$.

After exposure to severe hypoxia, the alanine level $(n=5)$ was $0.04 \pm 0.01 \mu \mathrm{mol} \mathrm{g}{ }^{-1}$ and after recovery, the alanine $(n=3)$ was still $0.04 \pm 0.01 \mu \mathrm{mol} \mathrm{g}^{-1}$ The normoxic alanine concentration is $0.07 \pm 0.05 \mu \mathrm{mol} \mathrm{g}^{-1}$ (data from Hagerman \& Szaniawska 1990) and starts to accumulate only after approximately $20 \mathrm{~h}$ of exposure to sulfide (Hagerman \& Vismann 1993).

\section{Reduced sulfur species}

Concentrations of sulfide, thiosulfate and sulfite at the start of recovery from the sulfide exposure and at the end of recovery are shown in Table 2 . Of the total $50.5 \mathrm{nmol} \mathrm{g}^{-1}$ reduced sulfur present at the start of 
Table 2. Reduced sulfur in different parts of Saduria entomon during the recovery from sulfide exposure. All results are mean values \pm SEM $(n=6)$

\begin{tabular}{|c|c|c|c|c|c|}
\hline \multirow[b]{2}{*}{ Start of recovery } & \multirow[t]{2}{*}{$\begin{array}{l}\text { Sulfide } \\
\left(\mathrm{nmol} \mathrm{g}^{-1}\right)\end{array}$} & \multirow[t]{2}{*}{$\begin{array}{l}\text { Thiosulfate } \\
\left(\text { nmol g } g^{-1}\right)\end{array}$} & \multirow[t]{2}{*}{$\begin{array}{l}\text { Sulfite } \\
(\text { nmol g-1) }\end{array}$} & \multicolumn{2}{|c|}{$\begin{array}{c}\text { S atoms } \\
\left(\text { nmol g } g^{-1}\right)(\% \text { of total })\end{array}$} \\
\hline & & & & & \\
\hline Hemolymph & $12.0 \pm 0.2$ & $9.1 \pm 0.9$ & $0.0 \pm 0.0$ & $30.2 \pm 2.0$ & 60 \\
\hline Midqut gland & $3.0 \pm 0.1$ & $5.1 \pm 1.1$ & $0.0 \pm 0.0$ & $13.2 \pm 2.3$ & 26 \\
\hline Tissue & $1.1 \pm 0.2$ & $3.0 \pm 0.6$ & $0.0 \pm 0.0$ & $7.1 \pm 1.4$ & 14 \\
\hline Total & $16.1 \pm 0.5$ & $17.2 \pm 2.6$ & $0.0 \pm 0.0$ & $50.5 \pm 5.7$ & 100 \\
\hline \multicolumn{6}{|l|}{ End of recovery } \\
\hline Hemolymph & $0.3 \pm 0.0$ & $2.6 \pm 0.8$ & $0.3 \pm 0.2$ & $5.8 \pm 1.8$ & 28 \\
\hline Midgut gland & $1.5 \pm 0.3$ & $2.9 \pm 0.7$ & $1.8 \pm 1.6$ & $9.1 \pm 3.3$ & 44 \\
\hline Tissue & $1.0 \pm 0.2$ & $2.5 \pm 1.0$ & $0.0 \pm 0.0$ & $6.0 \pm 2.2$ & 28 \\
\hline Total & $2.8 \pm 0.5$ & $8.0 \pm 2.5$ & $2.1 \pm 1.8$ & $20.9 \pm 7.3$ & 100 \\
\hline \multicolumn{6}{|l|}{ Balance } \\
\hline Hemolymph & $-11.7 \pm 0.2$ & $-6.5 \pm 1.7$ & $0.3 \pm 0.2$ & $-24.4 \pm 3.8$ & 82 \\
\hline Midgut gland & $-1.5 \pm 0.4$ & $-2.2 \pm 1.8$ & $1.8 \pm 1.6$ & $-4.1 \pm 5.6$ & 14 \\
\hline Tissue & $-0.1 \pm 0.4$ & $-0.5 \pm 1.6$ & $0.0 \pm 0.0$ & $-1.1 \pm 3.6$ & 4 \\
\hline Total & $-13.3 \pm 1.0$ & $-9.2 \pm 5.1$ & $2.1 \pm 1.8$ & $-29.6 \pm 13.0$ & 100 \\
\hline
\end{tabular}

reduced sulfur level in the tissue found after recovery in the present study. The higher tissue sulfide levels seems to indicate that $S$. entomon in Vismann (1991b) were exposed to some sediment sulfide in the storage tank prior to experiments.

\section{Energetics of recovery}

Severe hypoxia. An Saduria entomon uses $0.87 \mathrm{mg} \mathrm{O}_{2} \mathrm{~g}^{-1}$ during $8 \mathrm{~h}$ when routine respiration $10.109 \mathrm{mg}$ $\mathrm{O}_{2} \mathrm{~g}^{-1} \mathrm{~h}^{-1}$ ) is assumed. The oxygen debt paid by $S$. entomon during the $8 \mathrm{~h}$ of recovery was $0.57 \pm 0.05 \mathrm{mg}$ $\mathrm{O}_{2} \mathrm{~g}^{-1}$ and lactate accounted for $0.25 \mathrm{mg} \mathrm{O}_{2} \mathrm{~g}^{-1}$ of that (i.e. $44 \%$ of the oxygen debt). The oxygen debt

recovery, $29.6 \mathrm{nmol} \mathrm{g}^{-1}$ disappeared during the $28 \mathrm{~h}$ of recovery. At the start of recovery, $60 \%$ of the reduced sulfur was present in the hemolymph. At the end of recovery, $44 \%$ of the remaining reduced sulfur was present in the midgut gland. During recovery, reduced sulfur concentration and composition in the tissue did not change significantly. Sulfite was not found at the start of recovery, but eventually accumulated to concentrations of $1.3 \mathrm{nmol} \mathrm{g}^{-1}$ in the midgut gland and $0.3 \mathrm{nmol} \mathrm{g}^{-1}$ in the hemolymph. The accumulation of $\mathrm{H}_{2} \mathrm{~S}$ and $\mathrm{S}_{2} \mathrm{O}_{3}{ }^{2-}$ in the midgut gland of Saduria entomon found by Vismann (1991b) was not found in the present study. When exposed to sulfide for $24 \mathrm{~h}$, the midgut gland turned black (Vismann 1991b). In the present study, no such color change was seen. Whether the difference is due to different exposure time or different handling prior to experiments (i.e. difference in sediment conditions in the storage tank) is not known, but the normoxic sulfide levels seem to indicate that the latter is the case (see below).

During recovery, $29.6 \mathrm{nmol}$ reduced sulfur $\mathrm{g}^{-1}$ disappeared and were assumed to be oxidized to $\mathrm{SO}_{4}{ }^{2-}$ (Table 2). This plus the $2.1 \mathrm{nmol} \mathrm{SO}_{3}{ }^{2-} \mathrm{g}^{-1}$ require $59.2 \mathrm{nmol} \mathrm{O} \mathrm{g}^{-1}$ to be oxidized. The $9.2 \mathrm{nmol} \mathrm{S}_{2} \mathrm{O}_{3}{ }^{2-}$ $\mathrm{g}^{-1}$ that disappeared contained $13.8 \mathrm{nmol} \mathrm{O}_{2} \mathrm{~g}^{-1}$. Total oxygen needed for sulfide oxidation during recovery was calculated to be $45.4 \mathrm{nmol} \mathrm{O}_{2} \mathrm{~g}^{-1}$ (= $1 \mu \mathrm{g} \mathrm{O}_{2} \mathrm{~g}^{-1}$ ). Whether the removed sulfide was oxidized or excreted is not known. However, the formation of sulfite during the recovery shows that some oxidation occurs. After recovery, the reduced sulfur in the hemolymph and in the midgut gland of Saduria entomon is similar to normoxic levels found by Vismann (1991b). However, the normoxic level of reduced sulfur in the tissue found by Vismann (1991b) is significantly higher than the after severe hypoxia is 'subnormal' (Herreid 1980). The metabolic rate, evaluated in terms of lactate accumulation, in $S$. entomon during severe hypoxia compared to the normoxic rate was thus reduced by approximately $70 \%$ Metabolic shutdown is a wellknown phenomenon in animals periodically exposed to hypoxic conditions. However, most crustaceans will not show metabolic shutdown; they react to hypoxia by showing escape responses. $S$. entomon is unusual because it stays and awaits the return of normoxia. In general, the oxygen debt can also appear 'subnormal' when anaerobic metabolites are excreted or only partly oxidized (Herreid 1980). In the present study, however, the lactate was measured and the oxygen to lactate ratio did not indicate that any significant excretion took place.

Hypoxia with sulfide. The oxygen debt in Saduria entomon after sulfide exposure was $2.74 \mathrm{mg} \mathrm{O}_{2} \mathrm{~g}^{-1}$. The part of the oxygen debt which was due to lactate removal was $0.54 \mathrm{mg} \mathrm{O} \mathrm{O}_{2} \mathrm{~g}^{-1}$ (i.e. $20 \%$ of the oxygen debt). The oxygen debt after sulfide exposure is 'supernormal' (Herreid 1980). The metabolic rate (evaluated in terms of lactate) of $S$, entomon in hypoxia with presence of sulfide compared to that of normoxia decreased by approximately $38 \%$. In contrast to the $70 \%$ metabolic shutdown seen in hypoxia the metabolism decreases significantly less when sulfide was present. This accords with the increased consumption of energetic reserves seen in $S$. entomon exposed for $48 \mathrm{~h}$ to an oxygen tension of 4.0 to $6.7 \mathrm{kPa}$ and $150 \mu \mathrm{M}$ total sulfide (Hagerman \& Vismann 1993). The phenomenon of 'supernormal' oxygen debt has also been found in other crustaceans (Taylor et al. 1977, Butler et al. 1978). In these studies, the supernormal oxygen debt is related to 
succinate accumulation and regeneration of blood oxygen.

The part of the oxygen debt related to removal of reduced sulfur is as little as $0.04 \%$. Thus, sulfide oxidation during recovery does not contribute significantly to the oxygen debt. Using the data of Vismann (1991b), in which the midgut gland was found to accumulate reduced sulfur, the oxygen demand for sulfide oxidation during recovery was calculated to have been about 10 times higher than that of the present result. Using these data, the sulfide oxidation would, however, still contribute less than $0.5 \%$ of the total oxygen consumption during recovery. The oxidation of sulfide during recovery has also been investigated in the bivalve Scrobicularia plana, for which Oeschger \& Pedersen (1994) found that it did not contribute significantly to the oxygen debt.

The remaining $80 \%\left(2.2 \mathrm{mg} \mathrm{O}_{2} \mathrm{~g}^{-1}\right)$ of the observed oxygen debt cannot be explained in terms of oxidation of reduced sulfur or anaerobic metabolites. Alternatively, it could be caused by an increased locomotory activity, as seen during the first $3 \mathrm{~h}$ of the normoxic experiments (Fig. 3). However, in the present study, no locomotory activity was seen in Saduria entomon recovering from sulfide exposure. Processes such as, e.g., restoring jonic and osmotic levels, regulation of cellular ionic composition, protein synthesis, regeneration of phosphogen, regeneration of ATP stores and restoration of enzyme levels are obvious candidates for explaining the remaining oxygen debt. These processes are likely to have been arrested during sulfide exposure as shown for hemocyanin synthesis in $S$. entomon exposed to sulfide (Hagerman \& Vismann 1993). Replenishment of physically dissolved oxygen and hemocyanin-bound oxygen can only account for approximately $0.2 \%$ of the $2.2 \mathrm{mg} \mathrm{O}_{2} \mathrm{~g}^{-1}$.

In conclusion, the oxidation of anaerobic metabolites and reduced sulfur can only explain $20 \%$ of the oxygen debt seen in Saduria entomon recovering from sulfide exposure. Since no locomotory activity was seen, the majority of the oxygen debt is related to some not yet identified activities. These take place during recovery and are most likely concerned with restoring arrested processes. This suggests that some effects of sulfide on animal physiology have hitherto been overlooked. Future studies will address the identification of these physiological mechanisms.

Acknowledgements. We are indebted to Dr Eva Sandberg and Prof. Anna Szaniawska for supplying the experimental anmals and to Merete Allerup for technical assistance. This study was supported by the Danish Sclence Research Council, grant no. 11-8391 and by EC, MAST-2, grant no. MAS2CT93-0058.

\section{LITERATURE CITED}

Bagarinao T (1992) Sulfide as an environmental factor and toxicant: tolerance and adaptations in aquatic organisms. Aquat Toxicol 24:21-62

Bagannao T, Vetter RD (1990) Oxidative detoxification of sulfide by mitochondria of the California killifish Fundulus parvipinnis and the speckled sanddab Citharichthys stigmaeus. J Comp Physiol 160B:519-527

Bridges CR, Brand AR (1980) The effect of hypoxia on oxygen consumption and blood lactate levels of some marine crustacea. Comp Biochem Physiol 65 A:399-409

Butler P, Taylor E, McMahon B (1978) Respiratory and circulatory changes in the lobster (Homarus vulgaris) during long term exposure to moderate hypoxia. J Exp Biol 73: $131-146$

Ellington WR (1983) The recovery from anaerobic matabolism in invertebrates. J Exp Zool 228:431 -444

Fahey RC, Newton GL (1987) Determination of low-molecularweight thiols using monobromobimane fluorescent labeling and high-performance liquid chromatography. Methods Enzymol 143:85-97

Forstner H (1983) An automated multi-chamber intermittentflow respirometer. In: Gnaiger E, Forstner H (eds) Polarographic oxygen sensors. Aquatic and physiological applications. Springer-Verlag, Berlin, p 111-126

Gardner WS, Miller WH (1980) Reverse phase liquid chromatographic analysis of amino acids after reaction with o-phthalaldehyde. Anal Biochem 101:61-65

Hagerman L, Szaniawska A (1988) Respiration, ventilation and circulation under hypoxia in the glacial relict Saduria (Mesidotea) entomon. Mar Ecol Prog Ser 47:55-63

Hagerman L, Szaniawska A (1990) Anaerobic metabolic strategy of the glacial relict isopod Saduria (Mesidotea) entomon. Mar Ecol Prog Ser 59:91-96

Hagerman L, Vismann B (1993) Anaerobic metabolism, hypoxia and hydrogen sulphide in the brackish water isopod Saduria entomon (L.). Ophelia 38:1-11

Hagerman L, Vismann B (1995) Anaerobic metabolism in the shrimp Crangon crangon exposed to hypoxia, anoxia and hydrogen sulfide. Mar Biol 123:235-240

Hagerman L, Vismann B (1997) Oxygen binding characteristics of haemocyanin in the Baltic isopod Saduria entomon. Ophelia (in press)

Herreid CF II (1980) Hypoxia in invertebrates. Comp Biochem Physiol 67(A):311-320

Hochacka PW, Somero GN (1973) Strategies of biochemical adaptation. Saunders, Philadelphia

Lehninger AL (1976) Biochemistry, 2nd edn. Worth Publishers, New York

National Research Council, Division of Medical Science, Subcommittee on hydrogen sulfide (1979) Hydrogen sulfide. University Press, Baltimore

Oeschger R, Pedersen TF (1994) Influence of anoxia and hydrogen sulphide on the energy metabolism of Scrobicularia plana (da Costa) (Bivalvia). J Exp Mar Biol Ecol 184: $255-268$

Oeschger R, Vetter RD (1992) Sulfide detoxification and tolerance in Halicryptus spinolosus (Priapulida): a multiple strategy. Mar Ecol Prog Ser 86:167-179

Oeschger R, Vismann B (1994) Sulphide tolerance in Heteromastus fillformis (Polychaeta): mitochondrial adaptations. Ophelia 40:147-158

Powell MA. Somero GN (1986) Hydrogen sulfide oxidation is coupled to oxidative phosphorylation in mitochondria of Solemya reidi. Science 233:563-566

Pritchard AW, Eddy S (1979) Lactate formation in Callianassa 
Californiensis and Upogebia pugettensis (Crustacea: Thalassinidea). Mar Biol 50:249-253

Revsbech NP, Ward DM (1983) Oxygen microelectrode that is insensitive to medium chemical composition: used in an acid microbial mat dominated by Cyandum caldarium. Appl Environ Microbiol 45:755-759

Somero GN, Childress JJ, Anderson AE (1989) Transport, metabolism, and detoxification of hydrogen sulfide in animals from sulfide-rich marine environments. CRC Crit Rev Aquat Sci 1:591-614

Stryer L (1975) Biochemistry. WH Freeman \& Co, San Francisco

Taylor E, Butler P, Al-Wassia A (1977) Some responses of the shore crab Carcinus maenas (L.) during environmental hypoxia, at different acclimation temperatures and salinities. J Comp Physiol 122:391-402

Theede H, Ponat A. Hiroki K, Schlieper C (1969) Studies on the resistance of marine bottom invertebrates to oxygendeficiency and hydrogen sulphide. Mar Biol 2:325-337

This article was presented by T. Fenchel (Senior Editorial Advisor), Helsingor, Denmark
Vetter RD, Matrai PA, Javor B, O'Brien J (1989) Reduced sulfur compounds in the marine environment: analysis by high-performance liquid chromatography. Symp Ser Am Chem Soc 393:243-261

Vismann B (1990) Sulfide detoxification and tolerance in Nereis (Hediste) diversicolor and Nereis (Neanthes) virens (Annelida: Polychaeta). Mar Ecol Prog Ser 59:229-238

Vismann B (1991a) Sulfide tolerance: physiological mechanisms and ecological implications. Ophelia $34: 1-27$

Vismann B (1991b) The physiology of sulfide detoxification in the 1sopod Saduria (Mesidotea) entomon (L.). Mar Ecol Prog Ser 76:283-293

Vismann B (1996) The sulfide electrode and a set-up automatically controlling sulfide, oxygen and $\mathrm{pH}$. J Exp Mar Biol Ecol (in press)

Völkel S, Grieshaber MK (1992) Mechanisms of sulphide tolerance in the peanut worm, Sipunculus nudus (Sipunculidae) and in the lugworm, Arenicola marina (Polychaeta). J Comp Physiol 162B:469-477

Manuscript first received: August 9,1996

Revised version accepted: September 3, 1996 